\title{
Stenothermobacter spongiae gen. nov., sp. nov., a novel member of the family Flavobacteriaceae isolated from a marine sponge in the Bahamas, and emended description of Nonlabens tegetincola
}

\author{
Stanley C. K. Lau, ${ }^{1}$ Mandy M. Y. Tsoi, ${ }^{1}$ Xiancui Li, ${ }^{1}$ loulia Plakhotnikova, ${ }^{1}$ \\ Sergey Dobretsov, ${ }^{1}$ Madeline Wu, ${ }^{1}$ Po-Keung Wong, ${ }^{2}$ Joseph R. Pawlik ${ }^{3}$ \\ and Pei-Yuan Qian ${ }^{1}$ \\ ${ }^{1}$ Coastal Marine Laboratory/Department of Biology, The Hong Kong University of Science and \\ Technology, Clear Water Bay, Kowloon, Hong Kong SAR \\ ${ }^{2}$ Department of Biology, The Chinese University of Hong Kong, Shatin, NT, Hong Kong SAR \\ ${ }^{3}$ Center for Marine Science, University of North Carolina at Wilmington, USA
}

Correspondence

Pei-Yuan Qian

boqianpy@ust.hk

\begin{abstract}
A bacterial strain, UST030701-156 ${ }^{\top}$, was isolated from a marine sponge in the Bahamas. Strain UST030701-156 ${ }^{\top}$ was orange-pigmented, Gram-negative, rod-shaped with tapered ends, slowly motile by gliding and strictly aerobic. The predominant fatty acids were a15:0, i15:0, i15:0 3-OH, i1 $7: 03-\mathrm{OH}$, i1 $7: 1 \omega 9 \mathrm{c}$ and summed feature 3, comprising i15:0 2-OH and/or $16: 1 \omega 7 c$. MK-6 was the only respiratory quinone. Flexirubin-type pigments were not produced. Phylogenetic analysis based on 16S rRNA gene sequences placed UST030701-156 ${ }^{\top}$ within a distinct lineage in the family Flavobacteriaceae, with $93.3 \%$ sequence similarity to the nearest neighbour, Nonlabens tegetincola. The DNA G $+C$ content of UST030701-156 ${ }^{\top}$ was $41 \cdot 0$ mol\% and was much higher than that of $N$. tegetincola (33.6 mol\%). Strain UST030701-156 ${ }^{\top}$ can be distinguished from other members of the Flavobacteriaceae by means of a number of chemotaxonomic and phenotypic characteristics. It is proposed, therefore, that UST030701-156 ${ }^{\top}$ represents a novel taxon designated Stenothermobacter spongiae gen. nov., sp. nov. The type strain is UST030701-156 ${ }^{\top}$ (=NRRL B-41138 $\left.{ }^{\top}=\mathrm{JCM} 13191^{\top}\right)$. Carbon-source utilization by $N$. tegetincola was re-examined and an emended description is therefore included.
\end{abstract}

The family Flavobacteriaceae, belonging to the phylum 'Bacteroidetes', accommodates a large number of bacteria isolated from marine eukaryotes (Bernardet et al., 1996). For example, Salegentibacter holothuriorum is from a sea cucumber (Nedashkovskaya et al., 2004), Mesonia algae and Formosa algae are from macroalgae (Nedashkovskaya et al., 2003; Ivanova et al., 2004), current members of the genus Winogradskyella are from macroalgae and sponges (Nedashkovskaya et al., 2005a; Lau et al., 2005a) and Gramella echinicola, Leeuwenhoekiella aequorea KMM 6066 and Salegentibacter mishustinae are from the sea urchin Strongylocentrotus intermedius (Nedashkovskaya et al.,

The GenBank/EMBL/DDBJ accession number for the 16S rRNA gene sequence of strain UST030701-156 ${ }^{\top}$ is DQ064789.

A neighbour-joining dendrogram for strain UST030701-156 ${ }^{\top}$ and related species and the results of API 20E, API 20NE, API ZYM, API $50 \mathrm{CH}$ and MicroLog 3 tests are available as supplementary material in IJSEM Online.
$2005 b, c, d)$. On the basis of the polyphasic taxonomic data from the present study, we propose that the bacterial strain UST030701-156 ${ }^{\mathrm{T}}$, originating from a marine sponge, represents a novel genus of the Flavobacteriaceae.

The bacterial strain UST030701-156 ${ }^{\mathrm{T}}$ was isolated from tissue of the marine sponge Lissodendoryx isodictyalis in the Bahamas after $48 \mathrm{~h}$ cultivation at $30^{\circ} \mathrm{C}$ on an agar medium composed of $5 \mathrm{~g}$ peptone $\mathrm{l}^{-1}, 3 \mathrm{~g}$ yeast extract $\mathrm{l}^{-1}$ and $0 \cdot 22-\mu \mathrm{m}$-filtered sea water (hereafter referred to as marine agar). Colonies of UST030701-156 ${ }^{\mathrm{T}}$ were circular, 2-4 mm in diameter and convex with smooth surfaces, entire margins and a non-diffusible orange pigment. Unless otherwise specified, all characteristics described hereafter are based on cultures grown on marine agar for $48 \mathrm{~h}$ at $30^{\circ} \mathrm{C}$. The optimum temperature for the growth of UST030701-156 ${ }^{\mathrm{T}}$ was $28-30{ }^{\circ} \mathrm{C}$.

The nearly complete 16S rRNA gene sequence of UST030701-156 ${ }^{\mathrm{T}}$ (1399 bp) was obtained bidirectionally 


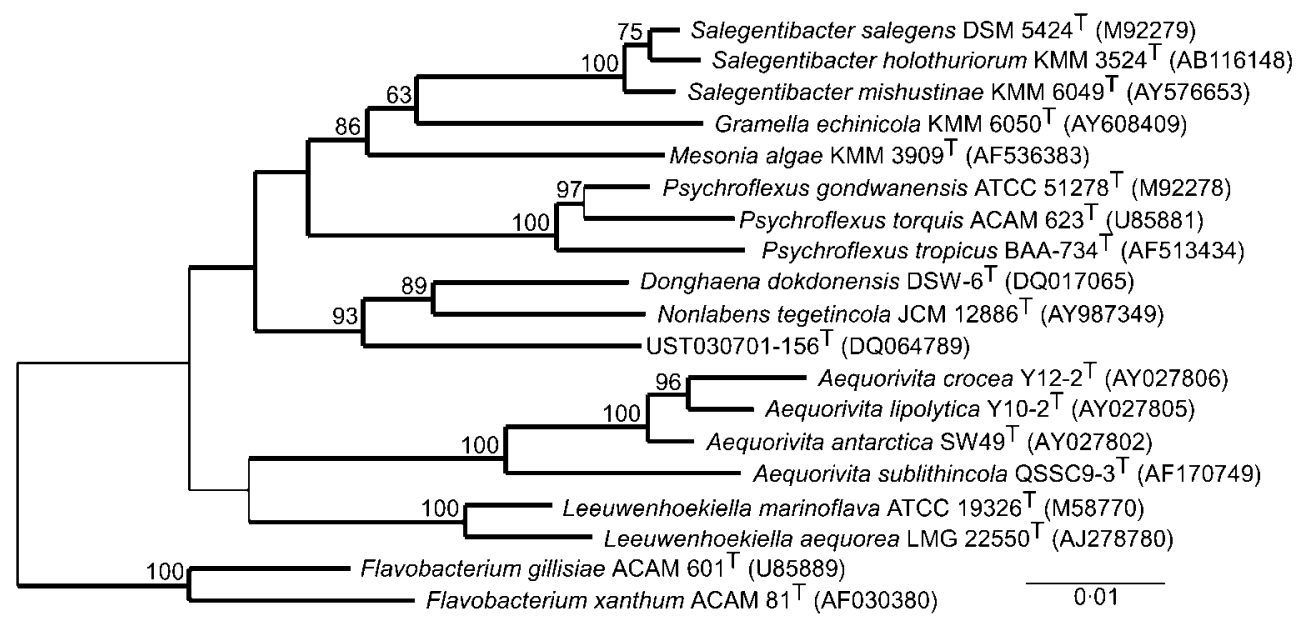

Fig. 1. Neighbour-joining dendrogram showing the estimated phylogenetic relationships among USTO30701-156 ${ }^{\top}$ and related species on the basis of $16 \mathrm{~S}$ rRNA gene sequences. Strains belonging to the genus Flavobacterium served as outgroups. Thicker lines indicate branches also found in maximum-likelihood and maximum-parsimony trees. Bootstrap values $>50 \%$ (500 replicates) are indicated at nodes. GenBank accession numbers are shown in parentheses. Bar, 1 nucleotide substitution per 100 nucleotides.

with replications $(n=3)$ as described elsewhere (Lau et al., 2004). Comparison of the nearly complete $16 \mathrm{~S}$ rRNA gene sequence of UST030701-156 ${ }^{\mathrm{T}}$ with those available from GenBank revealed that UST030701-156 ${ }^{\mathrm{T}}$ is a member of the family Flavobacteriaceae. UST030701-156 ${ }^{\mathrm{T}}$ shared $93 \cdot 3$ and $93.6 \%$ sequence similarity with the two most closely related species, Nonlabens tegetincola (Lau et al., 2005b) and Donghaena dokdonensis (Yoon et al., 2006), respectively. The sequence similarity to other species was $\leqslant 90 \cdot 9 \%$. A neighbour-joining phylogenetic tree constructed using the ARB software package (Ludwig et al., 2004) showed that UST030701-156 ${ }^{\mathrm{T}}$ belonged to a distinct branch, which clustered robustly ( $93 \%, 500$ replications) with $N$. tegetincola and D. dokdonensis (Fig. 1). Trees based on maximumparsimony and maximum-likelihood methods showed essentially the same topology (Fig. 1). The results of phylogenetic analysis suggest that UST030701-156 ${ }^{\mathrm{T}}$ represents a novel genus within the family Flavobacteriaceae. The distinction of UST030701-156 ${ }^{\mathrm{T}}$ from the closest relative, N. tegetincola, is further supported by the substantial difference in their DNA G + C contents: the value for UST030701-156 ${ }^{\mathrm{T}}$ is $41 \cdot 0 \pm 0 \cdot 2 \mathrm{~mol} \%$ (three replicates) while that for N. tegetincola is $33 \cdot 6 \pm 0 \cdot 2 \mathrm{~mol} \%$ (Lau et al., 2005b). The DNA G +C content was determined by using an HPLC method according to Mesbah et al. (1989).

The predominant fatty acids $(>5 \%)$ of UST030701-156 ${ }^{\mathrm{T}}$ were a15:0, i15:0, i15:0 3-OH, i17:0 3-OH, i17: $1 \omega 9 c$ and summed feature 3 (comprising i15:0 2-OH and/or $16: 1 \omega 7 c$ ) (altogether representing $76 \cdot 2 \%$ of the total), as determined using the Sherlock Microbial Identification System according to the manufacturer's protocol (Table 1). This fatty acid profile differed from that described for $N$. tegetincola by the absence of $18: 0$ and by having a smaller amount of i16:0 (Table 1). MK-6 was the only respiratory quinone in UST030701-156 ${ }^{\mathrm{T}}$, as determined using an HPLC method according to Collins (1994). Menaquinones extracted from Cellulophaga lytica ATCC $23178^{\mathrm{T}}$ (Johansen et al., 1999) and Pedobacter heparinus ATCC $13125^{\mathrm{T}}$ (Steyn et al., 1998) served as references for MK-6 and MK-7, respectively.

Anaerobic growth was examined using the Oxoid Anaerobic System. The requirement for $\mathrm{NaCl}$ was tested in a medium containing $\left(1^{-1}\right) 5 \mathrm{~g} \mathrm{MgCl}_{2}, 2 \mathrm{~g} \mathrm{MgSO}_{4}, 0 \cdot 5 \mathrm{~g} \mathrm{CaCl}_{2}, 1 \mathrm{~g}$

Table 1. Comparison of major cellular fatty acids of UST030701-156 ${ }^{\top}$ and N. tegetincola UST030701-324

Both strains were grown at $30^{\circ} \mathrm{C}$ on marine agar for $48 \mathrm{~h}$. Values are mean percentages $\pm \mathrm{SD}$ of total fatty acids. Data for N. tegetincola are from Lau et al. (2005b). -, Not detected.

\begin{tabular}{|lcc|}
\hline Fatty acid & $\begin{array}{c}\text { Strain } \\
\text { UST030701-156 }\end{array}$ & $\begin{array}{c}\text { N. tegetincola } \\
\text { UST030701-324 }^{\mathbf{T}}\end{array}$ \\
\hline Unknown 13.6 & $4 \cdot 0 \pm 1 \cdot 1$ & $6 \cdot 1 \pm 1 \cdot 8$ \\
i14:0 & $0 \cdot 5 \pm 0 \cdot 0$ & $2 \cdot 1 \pm 0 \cdot 8$ \\
a15:0 & $6 \cdot 2 \pm 0 \cdot 7$ & $3 \cdot 8 \pm 2 \cdot 3$ \\
i15:0 & $38 \cdot 1 \pm 0 \cdot 5$ & $33 \cdot 1 \pm 6 \cdot 4$ \\
i15:0 3-OH & $6 \cdot 2 \pm 0 \cdot 3$ & $5 \cdot 4 \pm 3 \cdot 0$ \\
i16:0 & $1 \cdot 9 \pm 0 \cdot 4$ & $6 \cdot 8 \pm 0 \cdot 4$ \\
i16:0 3-OH & $3 \cdot 4 \pm 0 \cdot 3$ & $5 \cdot 7 \pm 3 \cdot 1$ \\
$17: 1 \omega 6 c$ & $1 \cdot 7 \pm 0 \cdot 3$ & $2 \cdot 2 \pm 0 \cdot 4$ \\
i17: $1 \omega 9$ c & $5 \cdot 7 \pm 1 \cdot 4$ & $3 \cdot 5 \pm 0 \cdot 8$ \\
i17:0 3-OH & $11 \cdot 2 \pm 0 \cdot 3$ & $13 \cdot 7 \pm 5 \cdot 5$ \\
$18: 0$ & - & $2 \cdot 5 \pm 0 \cdot 0$ \\
Summed feature $3 *$ & $8 \cdot 8 \pm 1 \cdot 2$ & $7 \cdot 5 \pm 3 \cdot 6$ \\
\hline
\end{tabular}

${ }^{\star}$ Comprises i15:0 2-OH and/or 16:1 $1 \omega 7 c$. 
$\mathrm{KCl}, 5 \mathrm{~g}$ peptone and various amounts of $\mathrm{NaCl}$, adjusted to $\mathrm{pH} 7 \cdot 5$ using $\mathrm{KOH}$ (Isnansetyo \& Kamei, 2003). Cell morphology was examined using scanning electron microscopy (JEOL 7600F) according to the procedures described by Neu et al. (2001) (see Supplementary Fig. S1, available in IJSEM Online, for a scanning electron micrograph). The Gram-stain reaction was determined using light microscopy according to Smibert \& Krieg (1994). Gliding motility was determined using phase-contrast light microscopy after growth on quarter-strength marine 2216 medium solidified with $1 \%$ agar according to Bowman (2000). Susceptibility to antibiotics was tested according to Acar (1980). Flexirubintype pigment production and carboxylmethylcellulose hydrolysis were determined according to Bernardet et al. (2002). Casein hydrolysis was determined according to Norris et al. (1985); hydrolysis of chitin and Tweens 20, 40 and 80 was determined according to Baumann \& Baumann (1988). Oxidase and catalase activities and the hydrolysis of agar, DNA and starch were tested according to Smibert \& Krieg (1994). Other enzymic activities, the substrateutilization pattern, nitrate reduction and the production of $\mathrm{H}_{2} \mathrm{~S}$, indole and acetoin were determined by using the commercial systems API 20E, API 20NE, API $50 \mathrm{CH}$, API ZYM (bioMérieux) and MicroLog 3 (Biolog). Cells for inoculation to the API systems were suspended in a sterile solution of sea-water mix at $22 \%$ salinity (MacDonell et al., 1982). The phenotypic characteristics of UST030701-156 ${ }^{\mathrm{T}}$ are given in the species description. Detailed results obtained from the API and MicroLog 3 systems are provided in Supplementary Tables S1-S3. The MicroLog 3 system was also used to test for the utilization of carbon sources by N. tegetincola UST030701-324 ${ }^{\mathrm{T}}$. Results are given in the emended description of $N$. tegetincola and Supplementary Table S3.

Chemotaxonomic and phenotypic characteristics that distinguish UST030701-156 ${ }^{\mathrm{T}}$ from other genera of the Flavobacteriaceae are given in Tables 1 and 2. Strain UST030701-156 ${ }^{\mathrm{T}}$ differs from $N$. tegetincola by (i) having a higher DNA G $+C$ content, (ii) not being able to hydrolyse DNA, (iii) having gliding motility and a different cell morphology, (iv) growing in a narrower temperature range, (v) having $\alpha$-glucosidase and $\beta$-galactosidase activities and (vi) having a different carbon-source utilization pattern (refer to Supplementary Tables S2 and S3 for a detailed comparison). Strain UST030701-156 ${ }^{\mathrm{T}}$ differs from the members of Psychroflexus by (i) having different cell morphology and a different fatty acid profile, (ii) having a higher DNA G + C content, (iii) being less halotolerant and psychrotolerant and (iv) having $\beta$-galactosidase activity but not $\beta$ glucosidase activity. Additionally, UST030701-156 ${ }^{\mathrm{T}}$ can be distinguished from the members of Mesonia, Gramella and Salegentibacter by means of the traits detailed in Table 2. Molecular evidence, together with the chemotaxonomic and phenotypic characteristics, suggests that strain UST030701-156 ${ }^{\mathrm{T}}$ constitutes a novel genus within the family Flavobacteriaceae.

\section{Description of Stenothermobacter gen. nov.}

Stenothermobacter (Ste.no.ther'mo.bac'ter. Gr. adj. stenos narrow; Gr. adj. thermos hot; N.L. masc. n. bacter rod; N.L. masc. n. Stenothermobacter a rod with narrow temperature range, pertaining to the narrow temperature range that supports growth of UST030701-156 ${ }^{\mathrm{T}}$ ).

Table 2. Differentiation of UST030701-156 ${ }^{\top}$ from closely related genera

+, Positive; -, negative; ND, not determined; V, variable. Data for reference taxa are from Lau et al. (2005b), Bowman et al. (1998), Donachie et al. (2004), McCammon \& Bowman (2000) and Nedashkovskaya et al. (2003, 2004, 2005b, c).

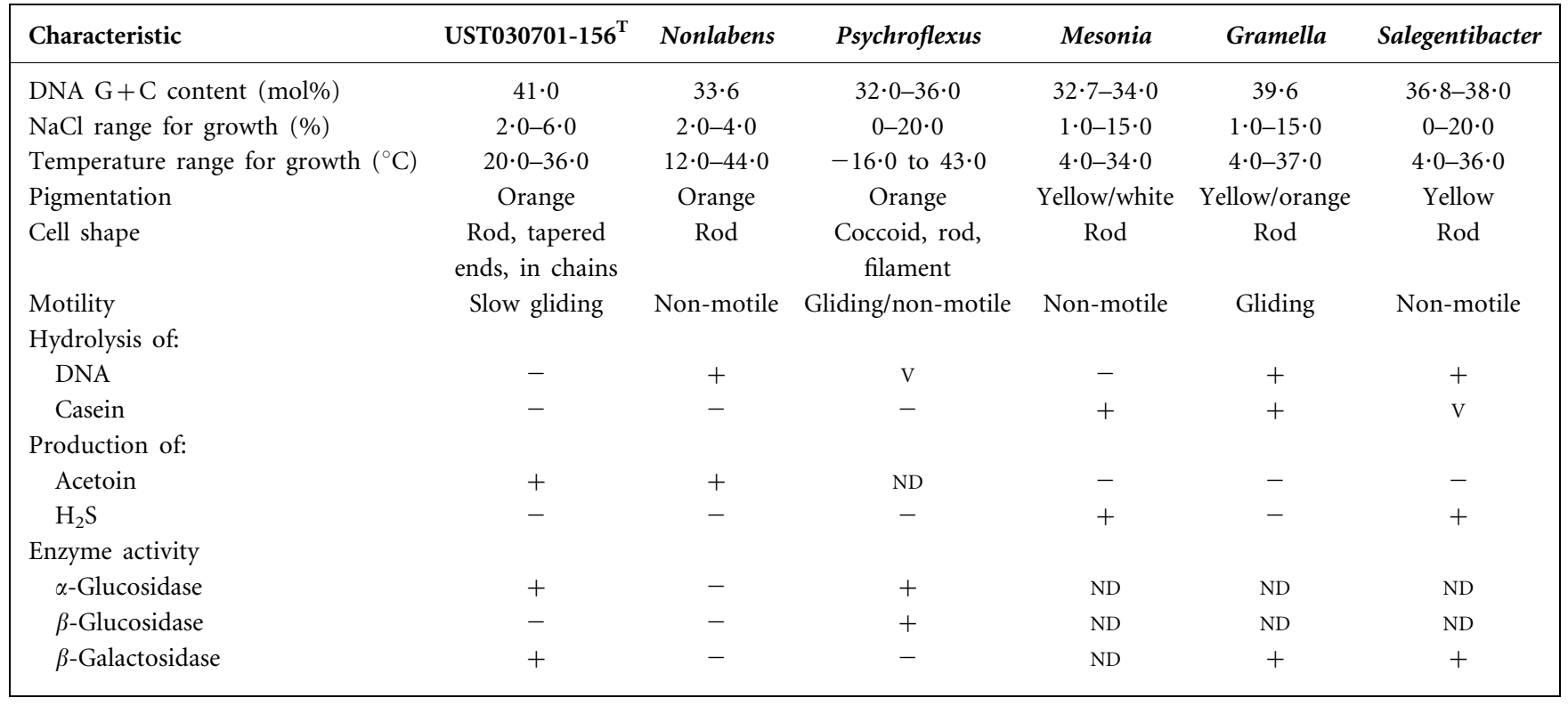


Cells are Gram-negative rods ( $>2.5 \mu \mathrm{m}$ in length) with tapered ends forming chains of up to four cells. Strictly aerobic. Chemo-organotrophic. MK-6 is the only respiratory quinone. Oxidase-positive. Catalase activity is very weak. Phylogenetic analysis based on the 16S rRNA gene sequence indicates that Stenothermobacter is a member of the family Flavobacteriaceae. The genus contains one species, Stenothermobacter spongiae, which is the type species.

\section{Description of Stenothermobacter spongiae sp. nov.}

Stenothermobacter spongiae (spon'gi.ae. L. gen. n. spongiae of a sponge, pertaining to the isolation source of the type strain).

The description is as for the genus, with the following additions. Cells are slowly motile by gliding. Colonies on marine agar are orange in colour, circular, $2 \cdot 0-4 \cdot 0 \mathrm{~mm}$ in diameter and convex with smooth surfaces and entire margins. No diffusible pigment. Flexirubin-type pigments are not produced. Growth occurs at $20 \cdot 0-36 \cdot 0{ }^{\circ} \mathrm{C}\left(28 \cdot 0-30 \cdot 0{ }^{\circ} \mathrm{C}\right.$ optimum), at $\mathrm{pH} 6 \cdot 0-10 \cdot 0$ and at $2 \cdot 0-6 \cdot 0 \% \mathrm{NaCl}$. Susceptible to ampicillin, chloramphenicol, penicillin, streptomycin and tetracycline, but not to kanamycin. The DNA $\mathrm{G}+\mathrm{C}$ content is $41 \cdot 0 \mathrm{~mol} \%$. The predominant fatty acids $(>5 \%)$ are a15:0, i15:0, i15:0 3-OH, i17:0 3-OH, i17: $1 \omega 9 c$ and summed feature 3 (comprising i15:0 $2-\mathrm{OH}$ and/or $16: 1 \omega 7 c$ ) (altogether representing $76 \cdot 2 \%$ of the total). Produces acetoin, but not indole or $\mathrm{H}_{2} \mathrm{~S}$. Nitrate is not reduced. Hydrolyses gelatin, starch and Tweens 20, 40 and 80 , but not agar, casein, carboxylmethylcellulose, chitin or DNA. Positive for acid phosphatase, alkaline phosphatase, $\beta$-galactosidase, $\alpha$-glucosidase, $\alpha$-chymotrypsin, cystine arylamidase, leucine arylamidase, valine arylamidase, esterase (C4), esterase lipase (C8), lipase (C14), trypsin and naphthol-AS-BI-phosphohydrolase activities. Negative for $N$-acetyl- $\beta$-glucosaminidase, arginine dihydrolase, $\alpha$ fucosidase, $\alpha$-galactosidase, $\beta$-glucosidase, $\beta$-glucuronidase, $\alpha$-mannosidase, lysine decarboxylase, ornithine decarboxylase, tryptophan deaminase and urease activities. Growth occurs on the following sole carbon sources in the API 20E, API 20NE and API $50 \mathrm{CH}$ systems: D-arabinose, D-galactose, D-glucose, glycerol, D-mannitol, D-melibiose, D-sorbitol, starch and D-sucrose. No acid is produced from these carbon sources. The following carbon sources in the MicroLog 3 system are utilized: D-maltose, D-melibiose, D-raffinose, sucrose, monomethyl succinate, acetic acid, $\alpha$-ketoglutaric acid, $\alpha$-ketovaleric acid, propionic acid, L-alaninamide, L-alanine, L-alanyl glycine, L-aspartic acid, L-glutamic acid, glycyl L-aspartic acid, glycyl L-glutamic acid, L-ornithine and L-proline. Refer to Supplementary Tables S2 and S3 for full lists of carbon sources included in the API and MicroLog 3 systems.

The type strain is UST030701-156 ${ }^{\mathrm{T}}\left(=\mathrm{NRRL} B-41138^{\mathrm{T}}=\right.$ JCM $13191^{\mathrm{T}}$ ), isolated from tissue of the marine sponge Lissodendoryx isodictyalis in the Bahamas.

\section{Emended description of Nonlabens tegetincola}

The description remains as given by Lau et al. (2005b), but with the following modifications: able to utilize 57 carbon sources in the MicroLog 3 system, including $\alpha$-cyclodextrin, dextrin, glycogen, adonitol, D-arabitol, L-erythritol, Dfructose, L-fucose, D-galactose, $\alpha$-D-glucose, myo-inositol, $\alpha$-D-lactose, lactulose, maltose, D-mannitol, D-mannose, D-melibiose, methyl $\beta$-D-glucoside, D-psicose, D-raffinose, L-rhamnose, D-sorbitol, sucrose, D-trehalose, turanose, methylpyruvate, monomethyl succinate, acetic acid, citric acid, D-galactonic acid lactone, D-galacturonic acid, Dgluconic acid, D-glucosaminic acid, D-glucuronic acid, $\alpha$-hydroxybutyric acid, $\alpha$-ketobutyric acid, $\alpha$-ketoglutaric acid, $\alpha$-ketovaleric acid, DL-lactic acid, malonic acid, propionic acid, quinic acid, D-saccharic acid, succinamic acid, glucuronamide, L-alaninamide, L-alanine, L-alanyl glycine, L-aspartic acid, L-glutamic acid, glycyl L-aspartic acid, glycyl L-glutamic acid, L-ornithine, L-proline, L-serine, L-threonine and uridine. A full list of carbon sources included in the MicroLog 3 test system is available in Supplementary Table S3.

\section{Acknowledgements}

The authors thank Mr Ken Lau for the respiratory quinone analysis and Professor Hans G. Trüper for assistance with the Latin etymology. This work was supported by the RGC grants HKUST6240/04M and CA04/05.Sc01 (to P.-Y.Q.) and an NSF Biological Oceanography Program grant (OCE-0095724) to J. R.P.

\section{References}

Acar, J. F. (1980). The disc susceptibility test. In Antibiotics in Laboratory Medicine, pp. 24-54. Edited by V. Lorian. Baltimore: Williams \& Wilkins.

Baumann, P. \& Baumann, L. (1988). The marine gram-negative eubacteria: genera Photobacterium, Beneckea, Alteromonas, Pseudomonas and Alcaligenes. In The Prokaryotes, vol. 1, pp. 1302-1331. Edited by M. P. Starr, H. Stolp, H. G. Trüper, A. Balows \& H. Schlegel. Berlin: Springer.

Bernardet, J. F., Segers, P., Vancanneyt, M., Berthe, F., Kersters, K. \& Vandamme, P. (1996). Cutting a Gordian knot: emended classification and description of the genus Flavobacterium, emended description of the family Flavobacteriaceae, and proposal of Flavobacterium hydatis nom. nov. (basonym, Cytophaga aquatilis Strohl and Tait 1978). Int J Syst Bacteriol 46, 128-148.

Bernardet, J. F., Nakagawa, Y. \& Holmes, B. (2002). Proposed minimal standards for describing new taxa of the family Flavobacteriaceae and emended description of the family. Int J Syst Evol Microbiol 52, 1049-1070.

Bowman, J. P. (2000). Description of Cellulophaga algicola sp. nov., isolated from the surfaces of Antarctic algae, and reclassification of Cytophaga uliginosa (ZoBell and Upham 1944) Reichenbach 1989 as Cellulophaga uliginosa comb. nov. Int J Syst Evol Microbiol 50, 1861-1868.

Bowman, J. P., McCammon, S. A., Lewis, T., Skerratt, J. H., Brown, J. L., Nichols, D. S. \& McMeekin, T. A. (1998). Psychroflexus torquis gen. nov., sp. nov., a psychrophilic species from Antarctic sea ice, and reclassification of Flavobacterium gondwanense (Dobson et al. 
1993) as Psychroflexus gondwanense gen. nov., comb. nov. Microbiology 144, 1601-1609.

Collins, M. D. (1994). Isoprenoid quinones. In Chemical Methods in Prokaryotic Systematics, pp. 265-310. Edited by M. Goodfellow \& A. G. O'Donnell. Chichester: Wiley.

Donachie, S. P., Bowman, J. P. \& Alam, M. (2004). Psychroflexus tropicus sp. nov., an obligately halophilic Cytophaga-FlavobacteriumBacteroides group bacterium from an Hawaiian hypersaline lake. Int J Syst Evol Microbiol 54, 935-940.

Isnansetyo, A. \& Kamei, Y. (2003). Pseudoalteromonas phenolica sp. nov., a novel marine bacterium that produces phenolic antimethicillin-resistant Staphylococcus aureus substances. Int J Syst Evol Microbiol 53, 583-588.

Ivanova, E. P., Alexeeva, Y. V., Flavier, S., Wright, J. P., Zhukova, N. V., Gorshkova, N. M., Mikhailov, V. V., Nicolau, D. V. \& Christen, R. (2004). Formosa algae gen. nov., sp. nov., a novel member of the family Flavobacteriaceae. Int J Syst Evol Microbiol 54, 705-711.

Johansen, J. E., Nielsen, P. \& Sjoholm, C. (1999). Description of Cellulophaga baltica gen. nov., sp. nov. and Cellulophaga fucicola gen. nov., sp. nov. and reclassification of [Cytophaga] lytica to Cellulophaga lytica gen. nov., comb. nov. Int J Syst Bacteriol 49, 1231-1240.

Lau, S. C. K., Tsoi, M. M. Y., Li, X., Plakhotnikova, I., Wu, M., Wong, P.-K. \& Qian, P.-Y. (2004). Loktanella hongkongensis sp. nov., a novel member of the $\alpha$-Proteobacteria originating from marine biofilms in Hong Kong waters. Int J Syst Evol Microbiol 54, 2281-2284.

Lau, S. C. K., Tsoi, M. M. Y., Li, X. \& 7 other authors (2005a). Winogradskyella poriferorum sp. nov., a novel member of the family Flavobacteriaceae isolated from a sponge in the Bahamas. Int J Syst Evol Microbiol 55, 1589-1592.

Lau, S. C. K., Tsoi, M. M. Y., Li, X., Plakhotnikova, I., Dobretsov, S., Wong, P.-K., Pawlik, J. R. \& Qian, P.-Y. (2005b). Nonlabens tegetincola gen. nov., sp. nov., a novel member of the family Flavobacteriaceae isolated from a microbial mat in a subtropical estuary. Int J Syst Evol Microbiol 55, 2279-2283.

Ludwig, W., Strunk, O., Westram, R. \& 29 other authors (2004). ARB: a software environment for sequence data. Nucleic Acids Res 32, 1363-1371.

MacDonell, M. T., Singleton, F. L. \& Hood, M. A. (1982). Diluent composition for use of API 20E characterizing marine and estuarine bacteria. Appl Environ Microbiol 44, 423-427.

McCammon, S. A. \& Bowman, J. P. (2000). Taxonomy of Antarctic Flavobacterium species: description of Flavobacterium gillisiae sp. nov., Flavobacterium tegetincola sp. nov. and Flavobacterium xanthum sp. nov., nom. rev., and reclassification of [Flavobacterium] salegens as Salegentibacter salegens gen. nov., comb. nov. Int J Syst Evol Microbiol 50, 1055-1063.

Mesbah, M., Premachandran, U. \& Whitman, W. B. (1989). Precise measurement of the $\mathrm{G}+\mathrm{C}$ content of deoxyribonucleic acid by high-performance liquid chromatography. Int J Syst Bacteriol 39, 159-167.

Nedashkovskaya, O. I., Kim, S. B., Han, S. K. \& 7 other authors (2003). Mesonia algae gen. nov., sp. nov., a novel marine bacterium of the family Flavobacteriaceae isolated from the green alga Acrosiphonia sonderi (Kütz) Kornm. Int J Syst Evol Microbiol 53, 1967-1971.

Nedashkovskaya, O. I., Suzuki, M., Vancanneyt, M., Cleenwerck, I., Zhukova, N. V., Vysotskii, M. V., Mikhailov, V. V. \& Swings, J. (2004). Salegentibacter holothuriorum sp. nov., isolated from the edible holothurian Apostichopus japonicus. Int J Syst Evol Microbiol 54, 1107-1110.

Nedashkovskaya, O. I., Kim, S. B., Han, S. K. \& 9 other authors (2005a). Winogradskyella thalassocola gen. nov., sp. nov., Winogradskyella epiphytica sp. nov. and Winogradskyella eximia sp. nov., marine bacteria of the family Flavobacteriaceae. Int J Syst Evol Microbiol 55, 49-55.

Nedashkovskaya, O. I., Kim, S. B., Lysenko, A. M., Mikhailov, V. V., Bae, K. S. \& Kim, I. S. (2005b). Salegentibacter mishustinae sp. nov., isolated from the sea urchin Strongylocentrotus intermedius. Int J Syst Evol Microbiol 55, 235-237.

Nedashkovskaya, O. I., Kim, S. B., Lysenko, A. M., Frolova, G. M., Mikhailov, V. V., Bae, K. S., Lee, D. H. \& Kim, I. S. (2005c). Gramella echinicola gen. nov., sp. nov., a novel halophilic bacterium of the family Flavobacteriaceae isolated from the sea urchin Strongylocentrotus intermedius. Int J Syst Evol Microbiol 55, 391-394.

Nedashkovskaya, O. I., Vancanneyt, M., Dawyndt, P. \& 9 other authors (2005d). Reclassification of [Cytophaga] marinoflava Reichenbach 1989 as Leeuwenhoekiella marinoflava gen. nov., comb. nov. and description of Leeuwenhoekiella aequorea sp. nov. Int J Syst Evol Microbiol 55, 1033-1038.

Neu, B., Voigt, A., Mitlohner, R. \& 7 other authors (2001). Biological cells as templates for hollow microcapsules. J Microencapsul 18, 385-395.

Norris, J. R., Ribbons, D. W. \& Varma, A. K. (editors) (1985). Methods in Microbiology, vol. 18. London: Academic Press.

Smibert, R. M. \& Krieg, N. R. (1994). Phenotypic characteristics. In Methods for General and Molecular Biology, pp. 607-654. Edited by P. Gerhardt, R. G. E. Murray, W. A. Wood \& N. R. Krieg. Washington, DC: American Society for Microbiology.

Steyn, P. L., Segers, P., Vancanneyt, M., Sandra, P., Kersters, K. \& Joubert, J. J. (1998). Classification of heparinolytic bacteria into a new genus, Pedobacter, comprising four species: Pedobacter heparinus comb. nov., Pedobacter piscium comb. nov., Pedobacter africanus sp. nov. and Pedobacter saltans sp. nov. Proposal of the family Sphingobacteriaceae fam. nov. Int J Syst Bacteriol 48, 165-177.

Yoon, J.-H., Kang, S.-J., Lee, C.-H. \& Oh, T.-K. (2006). Donghaena dokdonensis gen. nov., sp. nov., isolated from sea water. Int J Syst Evol Microbiol 56, 187-191. 